\title{
EU CITIZENSHIP AND EU ENTITIES: NEW PERSPECTIVES FOR CITIZENS AND COMPANIES
}

\author{
AGNIESZKA GUZEWICZ*
}

\section{INTRODUCTION}

The contemporary European Union needs a stronger sense of identity to overcome its existing crises and divisions. Implementation of common European standards requires that the competing interests of Member States be reconciled in order to find a point of balance between the autonomy of legal systems and the idea of the internal market. EU law is constantly changing, which is reflected in the case law of the Court of Justice of the European Union constituting the acquis communautaire. In analysing judgments in the area of the EU citizenship and company law, one might discern a clear tendency of the Court of Justice to accentuate an EU identity, which is a source of rights for citizens or companies, independent of particular Member States' legal orders. EU identity manifests itself most strongly in the institution of EU citizenship, but in recent times the Court of Justice has emphasized the importance of identity also in connection with the operation of companies falling under Article 54 (1) of the Treaty on the Functioning of the European Union (TFEU) ${ }^{1}$, which will be the subject of further consideration.

\section{EU CITIZENSHIP AS A INDEPENDENT BASIS OF RIGHTS OF NATURAL PERSONS}

European Union citizenship is a legal bond connecting a natural person with the Union, granting a given person certain rights and imposing obligations (theoretically) on him/her ${ }^{2}$. The introduction of EU citizenship by the Maastricht Treaty resulted in the expansion of the subjective and

DOI: 10.2478/wrlae-2013-0004

* PhD candidate; University of Wroclaw, Faculty of Law, Administration and Economics, Department of Commercial and Business Law; a.guzewicz@prawo.uni.wroc.pl

${ }^{1}$ Treaty on the Functioning of the European Union [2012] OJ C326/47.

${ }^{2}$ See Adam Łazowski, 'Obywatelstwo Unii Europejskiej - uwagi teoretyczne i praktyczne w dziesięć lat po wejściu w życie Traktatu z Maastricht' in Eugeniusz Piontek, Anna Zawidzka (eds), Szkice z prawa Unii Europejskiej, t. I (Wolters Kluwer 2003) 135-136. 
objective scopes of natural persons' entitlements ${ }^{3}$. All Union citizens, regardless of whether they conduct economic activity, were given the opportunity to invoke the provisions of law stipulated in the Treaty. It should be noted that EU citizenship has strengthened the link between the Union and its citizens ${ }^{4}$.

Initially, EU citizenship was perceived symbolically, ${ }^{5}$ and its introduction was not linked with significant changes in the set of entitlements conferred under EU law upon the citizens of Member States ${ }^{6}$, except for the right to participate in municipal elections as well as elections to the European Parliament as well as diplomatic and consular protection ${ }^{7}$. In recent years, the Court of Justice has questioned this view of EU citizenship, and through its rulings it has imparted real significance to the entitlements resulting from TFEU ${ }^{8}$. The jurisprudence of the Court of Justice on EU citizenship has also been affected by amendments introduced into the Treaties.

Under the current wording of the relevant regulations, EU citizenship is mentioned in both Article 9 of the Treaty on European Union $(\mathrm{TEU})^{9}$ and in Article 20 of the TFEU. The TEU contains provisions of a general nature while the section from the TFEU regarding citizenship constitutes a complimentary set of regulations ${ }^{10}$.

According to Article 20 of the TFEU, 'Every person holding the nationality of a Member State shall be a citizen of the Union.' EU citizenship is acquired automatically by each natural person belonging to a Member State and 'shall be additional to (...) national citizenship.' This passage demonstrates a shift towards strengthening the institution of EU citizenship, since the previous provision stipulated that EU citizenship 'shall

\footnotetext{
${ }^{3}$ See Krystyna Kowalik-Bańczyk in Andrzej Wróbel (ed), Traktat o funkcjonowaniu Unii Europejskiej. Komentarz do art. 1-89 (Warsaw 2012) 437.

4 See Annette Schrauwen, 'The Future of EU Citizenship: Corrosion of National Citizenship?' (Amsterdam 2009) 2, available at: http://ssrn.com/abstract=1375413; Francis G Jacobs, 'Citizenship of the European Union-A Legal Analysis' (2007) 13 European Law Journal 591-610.

5 See Dimitry Kochenov, 'Ius Tractum of Many Faces: European Citizenship and the Difficult Relationship between Status and Rights' (2009) 15 Columbia Journal of European Law 172; Dora Kostakopoulou, 'European Union Citizenship: Writing the Future' (2007) 13 European Law Journal 623-628.

${ }^{6}$ See Samantha Besson, André Utzinger, 'Introduction: Future Challenges of European Citizenship_Facing a Wide-Open Pandora's Box' (2007) 13 European Law Journal 574.

7 See Dora Kostakopoulou, 'Ideas, Norms and European Citizenship: Explaining Institutional Change' (2005) 68 The Modern Law Review 234.

${ }^{8}$ See inter alia Cases C-224/98 Marie-Nathalie D'Hoop v Office national de l'emploi [2002] ECR I-06191; C-148/02 Carlos Garcia Avello v Belgian State [2003] ECR I-11613; Joined Cases C-502/01 and C-31/02 Silke Gaumain-Cerri v Kaufmännische KrankenkassePflegekasse and Maria Barth v Landesversicherungsanstalt Rheinprovinz [2004] ECR I06483; C-499/06 Halina Nerkowska v Zakład Ubezpieczeń Społecznych Oddzial w Koszalinie [2008] ECR I-03993; C-135/08 Janko Rottman v Freistaat Bayern [2010] ECR I-01449; C-34/09 Gerardo Ruiz Zambrano v Office national de l'emploi (ONEm) [2011] ECR I-01177.

${ }^{9}$ Treaty on European Union [2012] OJ C326/13.

${ }^{10}$ See Kowalik-Bańczyk (n 3 ) 441.
} 
complement (...) national citizenship. ${ }^{\prime 1}$ This change is not accidental or without meaning ${ }^{12}$. Recent decisions of the Court of Justice confirm that EU citizenship bestows upon citizens a guarantee of exercise of their rights as granted under the Treaty independently of those derived from the internal law of individual Member States - EU citizenship is becoming an independent structure, thereby strengthening the position of the individual with regard to the internal laws of the Member States ${ }^{13}$.

The new approach of the Court of Justice regarding the rights to which every citizen of the Union is entitled was clearly expressed in the Rottmann case ${ }^{14}$, in which the Court considered whether the loss of national citizenship (which, according to international law, falls within the competence of the Member States) might be adjudicated with respect to EU law if that loss results in the additional loss of EU citizenship. Janko Rottman, an Austrian citizen, settled in Germany and applied for German citizenship. Once his application was granted, he was denaturalized in Austria. However, the decision on naturalization in Germany was then reversed due to his withholding information of proceedings pending against him. Had this decision come into force, denaturalization would have given him the status of a stateless person, thereby causing the loss of EU citizen status ${ }^{15}$.

In his opinion to the Rottmann case, Advocate General Maduro advanced a very restrictive interpretation of the scope of EU citizenship, holding that a cross-border element was necessary in that case ${ }^{16}$. Advocate General Maduro identified such a foreign element, and declared the case to be admissible for a preliminary ruling ${ }^{17}$.

Having analysed the presented preliminary questions, the Court stated, in contrast to the approach taken by Advocate General Maduro in his Opinion, that it is not necessary to demonstrate the existence of a cross border element since:

It is clear that the situation of a citizen of the Union who, like the applicant in the main proceedings, is faced with a decision withdrawing his naturalisation, adopted by the authorities of one

\footnotetext{
${ }^{11}$ Article 17 of Treaty establishing the European Community [1997] OJ C340/173.

12 See Marek Safjan, Between Mangold and Omega: Fundamental Rights versus Constitutional Identity' (2012) 3 Il diritto dell'Unione europea 442-449. In the earlier literature, see Annette Schrauwen, 'European Union Citizenship in the Treaty of Lisbon: Any Change at All?' (2008) 1 Maastricht Journal of European and Comparative Law 55-64.

${ }^{13}$ See Safjan (n 12) 445.

${ }^{14}$ Case C-135/08 Janko Rottman (n 8).

${ }^{15}$ Case C-135/08 Janko Rottman (n 8) paras 22-28.

16 'However, even though a situation concerns a subject the regulation of which comes within the competence of the Member States, it falls within the scope of ratione materiae of Community law if it involves a foreign element, that is, a cross-border dimension', see Case C-135/08 Janko Rottman (n 8) Opinion of Advocate General Maduro, para 10. The link between the rights attached to EU citizenship and a cross-border element has also been perceived by doctrine, see inter alia Schrauwen (n 4) 3.

${ }^{17}$ Case C-135/08 Janko Rottman (n 8) Opinion of Advocate General Maduro, para 11; See also: Cases C-148/02 Garcia Avello (n 8) para 24; C-76/05 Herbert Schwarz and Marga Gootjes-Schwarz v Finanzamt Bergisch Gladbach [2007] ECR I-06849 para 87; C-209/03 The Queen, on the application of Dany Bidar v London Borough of Ealing and Secretary of State for Education and Skills [2005] ECR I-2119, para 33; C-403/03 Egon Schempp v Finanzamt München $V$ [2005] ECR I-06421 paras 17 and 18; C-499/06 Nerkowska (n 8) paras 26 to 29 .
} 
Member State, and placing him, after he has lost the nationality of another Member State that he originally possessed, in a position capable of causing him to lose the status conferred by Article $17 \mathrm{EC}$ and the rights attaching thereto falls, by reason of its nature and its consequences, within the ambit of European Union law (emphasis added). ${ }^{18}$

In other words, Member States are obliged to take EU law into account when exercising their powers in the sphere of nationality ${ }^{19}$. In its judgment the Court of Justice confirmed that a decision on revoking nationalization should be taken in the context of rights resulting from EU citizenship, respecting the principle of proportionality ${ }^{20}$. Thus, EU citizenship can no longer be perceived only as an institution supplementing national citizenship, but as an independent basis for the creation of specific entitlements for individuals ${ }^{21}$. After the Rottmann judgment, there can be no doubt that Member States do not wield absolute power over the granting and revocation of citizenship, but they must instead do so with regard for the acquis communautaire ${ }^{22}$. In that regard, the Rottmann case might be perceived as a revolution in the approach to the scope of rights resulting from EU citizenship, and it is a significant development in the context of understanding the notion of EU identity ${ }^{23}$.

\section{COMPANIES' EXISTENCE WITHIN THE INTERNAL MARKET}

In the case of natural persons, acquiring EU citizenship constitutes a preliminary condition to enjoying the freedom of establishment, whereas with respect to companies 'EU membership' plays a similar role. This 'membership' does not constitute an inherent trait of each company operating on the internal market. Placing a company under the EU legal

\footnotetext{
${ }^{18}$ Case C-135/08 Janko Rottman (n 8) para 42.

19 Case C-135/08 Janko Rottman (n 8) para 45. On the consequences of the Court's position, see Dimitry Kochenov, 'A Real European Citizenship; A New Jurisdiction Test; A Novel Chapter in the Development of the Union in Europe' (2011) 18 Columbia Journal of European Law 75-80.

${ }^{20}$ Case C-135/08 Janko Rottman (n 8) paras 56 and 58.

${ }^{21}$ See also Safjan (n 12) 442-449.

22 See also Dimitry Kochenov, 'Case C-135/08, Janko Rottmann v. Freistaat Bayern, Judgment of the Court (Grand Chamber) of 2 March 2010' (2010) 47 Common Market Law Review 1846. Moreover, according to settled case-law EU citizenship is intended to be 'the fundamental status of nationals of the Member States', see Cases C-184/99 Rudy Grzelczyk v Centre public d'aide sociale d'Ottignies-Louvain-la-Neuve [2001] ECR I-6193 para 31; Case C-200/02 Kunqian Catherine Zhu and Man Lavette Chen v Secretary of State for the Home Department [2004] ECR I-09925 para 25; Case C-76/05 Schwarz and Gootjes-Schwarz (n 17) para 86; C-34/09 Gerardo Ruiz Zambrano (n 8) para 41; C-256/11 Murat Dereci and Others v Bundesministerium für Inneres [2011], not yet published, para 62.

${ }^{23}$ On European Civic Identity, see inter alia Paul Magnette, 'How can one be European? Reflections on the Pillars of European Civic Identity' (2007) 13 European Law Journal 664-679.
} 
order is effected provided that the two conditions set out in article 54 (1) of TFEU are $\mathrm{met}^{24}$. As the cited provision states:

'Companies or firms formed in accordance with the law of a Member State and having their registered office, central administration or principal place of business within the Union shall (...) be treated in the same way as natural persons who are nationals of Member States.'

It should be emphasized that within the EU legal order, companies set up under the internal laws of the Member States are defined in Court of Justice jurisprudence as 'creatures of national law'25. If companies have their registered office ${ }^{26}$, central administration ${ }^{27}$ or principal place of business ${ }^{28}$ within the EU, they then fall under the subjective scope of protection of freedom of establishment. Under the wording of the Treaty, the necessity of fulfilling the two aforementioned conditions is not in doubt. However, a highly controversial position is supported by the Court of Justice according to which 'companies (...) exist only by virtue of the national legislation which determines their incorporation and functioning' ${ }^{29}$ (emphasis added). While the incorporation of a company depends on the national law of each Member State ${ }^{30}$, its further functioning must be considered in accordance with the provisions of the TFEU. Establishing an entity in accordance with the law of one of the Member States causes the creation of a European Union entity, i.e. an entity the rights and duties of which should be assessed in light of the TFEU rules on freedom of establishment ${ }^{31}$.

Differentiating between 'EU entities' and 'national entities' of companies is not a new concept. However, it has only recently gained

${ }^{24}$ See Jacek Napierała, Europejskie prawo spółek (Warsaw 2006) 12-13, Ewa Skibińska, Swoboda zakladania przedsiębiorstw przez osoby prawne (art. 43-48 TWE) (Warsaw 2008) 83-97; Aleksander Cieśliński, Wspólnotowe prawo gospodarcze (Warsaw 2003) 197-198.

${ }^{25}$ See Cases C-378/10 VALE Étési kft [2012], not yet published, para 27; C-210/06 CARTESIO Oktató és Szolgáltató bt [2008] ECR I-9641 para 104; 81/87 The Queen v H. M. Treasury and Commissioners of Inland Revenue, ex parte Daily Mail and General Trust plc [1988] ECR 5483 para 19.

26 The registered office (siège statutaire) of the company is the place chosen by the founders in the company statutes as well as the place of the registration, see Jean Schapira, Georges Le Tallec, Jean-Bernard Blaise, Laurence Idot, Droit européen des affaires, t. II (PUF 1999) 568; Guy Mustaki, Valérie Engammare, Droit européen des sociétés (Helbing Lichtenhahn 2009) 10. Some authors distinguish the registered office from the statutory seat, see inter alia Adam Opalski, Europejskie prawo spótek (Warsaw 2010) 90.

27 The central administration of the company is called the 'real seat' and means the place where the essential decisions are made by the board's members - senior management, see inter alia Maurice Cozian, Alain Viandier, Florence Deboissy, Droit des sociétés (Litec 2007) 106; Mustaki and Engammare (n 26) 11.

28 A principal place of business could be described as the location where the material resources and personnel of the company are concentrated, see inter alia Mustaki and Engammare (n 26) 11.

29 See Cases C-378/10 VALE (n 25) para 27; C-210/06 Cartesio (n 25) para 104; 81/87 Daily Mail and General Trust (n 25) para 19.

${ }^{30}$ See also Veronika Korom, Peter Metzinger, 'Freedom of Establishment for Companies: The European Court of Justice Confirms and Refines its Daily Mail Decision in the Cartesio Case C-210/06' (2009) 6 European Company and Financial Law Review 150.

31 See Elena Dubovizkaja, 'Uberseering-Rechtsprechung: Gerichtliche Klarstellung zur Niederlassungsfreiheit von Gesellschaften' (2003) 12 GmbH-Rundschau 698; Marek Szydło, 'The right of Companies to Cross-Border Conversion under the TFEU Rules on Freedom of Establishment' (2010) 3 European Company and Financial Law Review 429. 
particular importance in light of the Court of Justice jurisprudence regarding the EU citizenship to which natural persons are entitled. In the Rottmann case, the Court of Justice determined that the matter of loss of citizenship falling within the competence of the Member States cannot be examined separately from the entitlements arising from EU citizenship. In the case of companies, to which article 54 (1) TEU applies, it is time for the Court of Justice to confirm that the question of their functioning is not within the sole competence of Member States ${ }^{32}$.

While keeping in mind the passage that gives companies the right to enjoy the freedom of establishment ('companies (...) shall (...) be treated in the same way as natural persons who are nationals of Member States'), the consequences resulting from the proposed interpretation of article 54 (1) TFEU should be considered. Incorporation of an 'EU entity' depends on (as it results from the wording of the referred provision) incorporation of a 'national entity', whereas its further functioning (including dissolution) requires acquis communautaire to be taken into account, which means that in a particular situation the provisions of national law may not apply.

Problems regarding companies' mobility processes (including crossborder restructuring) have not been solved within the internal market ${ }^{33}$. A consequence of the dynamic development of European company law is a quest for instruments and legal solutions that would help ensure optimisation of conducting cross-border economic activity ${ }^{34}$. Companies enjoying the right to free movement under the freedom of establishment have long encountered obstacles to emigration and immigration ${ }^{35}$. Based on previous judgments, one may conclude that Member States are obliged to refrain from any action that could make it difficult for companies to enjoy the rights granted by the Court of Justice, e.g. they cannot freely (without reasonable justification and within limits determined by the Court of Justice) impede the processes under discussion; however, practice shows that companies' rights are not adequately protected.

\footnotetext{
32 See Agnieszka Guzewicz, 'Transgraniczne połączenia oraz przekształcenia spółek w świetle acquis communautaire' in Józef Frąckowiak (ed), Kodeks spótek handlowych po dziesięciu latach (Wrocław 2013) 638-641.

${ }^{33}$ On the differences between various Member States with regard to dissolution, liquidation and continuation of companies, see Jan Schouten, 'Continuation of the Legal Entity that has been Dissolved in a European Perspective' (2008) 5 European Company Law 13-19.

34 On the development of European company law, see inter alia: Michel Menjucq, La mobilité des sociétés dans l'espace européen (LGDJ 1997); André Decocq, Georges Decocq, Droit européen des affaires (L.G.D.J. 2003); Stefano Tafani, Roberto Caruso, Il nuovo diritto europeo delle società di capitali (Istituto Poligrafico dello Stato 2005); Stefan Grundmann, European Company Law. Organization, Finance and Capital Markets (Intersentia 2007); Mads Andenas, Frank Wooldridge, European Comparative Company Law (Cambridge University Press 2009); Gert-Jan Vossestein, Modernization of European Company Law and Corporate Governance. Some Considerations on its Legal Limits (Kluwer Law International 2010); Ulf Bernitz, Wolf-Georg Ringe (eds), Company Law and Economic Protectionism. New Challenges to European Integration (Oxford University Press 2010); Elisabetta Pederzini, Percorsi di diritto societario europeo (Giappichelli 2011).

35 See Cases 81/87 Daily Mail and General Trust (n 25); C-208/00 Überseering BV v Nordic Construction Company Baumanagement GmbH (NCC) [2002] ECR I-09919; C-411/03 SEVIC Systems $A G$ [2005] ECR I-10805; C-210/06 Cartesio (n 25); Case C378/10 VALE (n 25).
} 
Referring to the decision of the Court recently issued in the VALE case on 12 July 2012 concerning the right to cross-border conversion, many difficulties would have been avoided, and the rights resulting from the freedom of establishment would not have been violated, if the VALE company could have completed the process of cross-border conversion based on the 'EU entity' concept ${ }^{36}$.

In this case, a limited liability company governed by Italian law, $V A L E$ Costruzioni, asked to be removed from the commercial register, while at the same time intending to transfer its seat and economic activity to Hungary ${ }^{37}$. As a result of its application, the company was stricken from the commercial register in Italy. It was noted in the Italian register that the company had transferred its seat to Hungary. A few months later, the articles of association of VALE Épitési were adopted, and a limited liability company in a formation governed by Hungarian law was subsequently created $^{38}$. VALE Épitési applied for registration in the commercial register in Hungary while designating VALE Costruzioni as its predecessor in law $^{39}$ (that is, the company established and removed from the commercial register in Italy). The application was rejected first by the Commercial Court and then by the Appeals Court. Finally, the matter was referred to the Court of Justice for a preliminary ruling.

The company VALE had intended to complete a cross-border conversion process based on the Treaty rules on freedom of establishment ${ }^{40}$.

${ }^{36}$ Cross-border reorganization processes have already been analysed by the Court of Justice, however, the $V A L E$ case is the first case in which the Court considered the situation of cross-border conversion of a capital company. As far as previous decisions regarding the cross-border mobility of companies are concerned, the theses expressed in cases Überseering, SEVIC and Cartesio are of particular importance to the issues discussed. In its Überseering judgment the Court acknowledged that it was incompatible with the Treaty provisions on freedom of establishment for the host Member State to deny legal capacity to a company established in another Member State which had transferred its real seat to the first Member State whilst maintaining its status as a company incorporated under the legislation of the home Member State (C-208/00 Überseering (n 35) para 95). In the SEVIC case, the Court stressed that domestic regulation which introduces a general ban on entering cross-border mergers into a register while allowing such entries provided that both companies have their registered office in this Member State is inconsistent with the provisions on freedom of establishment (C-411/03 SEVIC Systems (n 35) para 31). Ruling in the next case, the Court of Justice acknowledged that cross-border transfer of a company's real seat with retention of its status as a company incorporated under the legislation of the home Member State does not enter into the scope of protection of freedom of establishment (C-210/06 Cartesio (n 25) para 110). Nevertheless, in the next points of its judgment, the Court affirmed the companies' right to cross-border conversion. In the aforementioned situation, a company moves its seat abroad, changing its statute and adapting to the requirements in force in the host Member State. The winding-up or liquidation of the company is not then possible in the home Member State, to the extent that the law of the host Member State allows such conversion (C-210/06 Cartesio (n 25) para 110).

37 Case C-378/10 VALE (n 25) para 9. Company VALE intended to transfer both its registered office and central administration from Italy to Hungary.

${ }^{38}$ Case C-378/10 VALE (n 25) para 10.

${ }^{39}$ Case C-378/10 VALE (n 25) para 11.

${ }^{40}$ See inter alia Pierre-Henri Conac, 'La CJUE reconnaît le transfert international de siège et ouvre la voie à une directive' (2012) 44 Recueil Le Dalloz 3009-3013; Thomas Mastrullo, 'La consécration du droit à la transformation transfrontalière des sociétés dans l'Union européenne' (2012) 38 La Semaine Juridique - entreprise et affaires 23-26; Ildo D. Mpindi, 'Mobilité des sociétés dans l'espace européen' (2012) 74 Revue Lamy droit des 
Pursuant to Italian law (State of departure), VALE Costruzioni no longer existed because of its removal from the commercial register - it was no longer a national entity. Moreover, VALE Épitési did not yet exist as a legal person under Hungarian law (State of destination) since registration of the company in Hungary was refused ${ }^{41}$. It could be qualified as a company in formation, and in consequence it had the legal capacity to initiate proceedings before both national and European courts ${ }^{42}$.

The company's non-existence under Italian law was one of the main grounds for refusal of its registration. Nevertheless, the Hungarian authorities did not take into consideration the documents issued by Italian authorities in order to determine if the company complied with the conditions laid down in the Member State of origin. The Court of Justice noted that, pursuant to the principle of effectiveness, during the registration procedure the authorities of the Member State of destination are required to take due account of documents obtained from the authorities of the Member State of departure ${ }^{43}$. In that regard the competent authorities shall examine if the said company maintains its status as an existing subject of law, which enables it to complete the cross-border conversion. It should be emphasized that the extract from the Italian commercial register confirmed that 'the company (had) moved to Hungary, ${ }^{44}$.

In these circumstances, there is no doubt that the converting company, VALE, complied with the two conditions provided for in Article 54 (1) TFEU and, consequently, could be recognized as an 'EU entity'. In its judgement the Court stated:

'that question relates to the examination, to be made by the Hungarian authorities, of the issue whether VALE Costruzioni disassociated itself from Italian law, in accordance with the conditions laid down thereunder, while retaining its legal personality, thereby enabling it to convert into a company governed by Hungarian law.' ${ }^{45}$ (emphasis added).

In this statement the Court acknowledged - indirectly - the existence and the importance of an 'EU entity' which can operate irrespective of national legal orders ${ }^{46}$.

affaires 15; Jérôme Vermeylen, 'Arrêt «VALE Építési »: la mobilité transfrontalière du siège statutaire est-elle un droit?'(2012) 9 Journal de droit européen 276-278.

${ }^{41}$ See Case C-378/10 VALE (n 25), Opinion of Advocate General Jääskinen, paras 44-45.

${ }^{42}$ Companies with legal personality as well as companies without legal personality yet having legal capacity are subject to the scope of protection of freedom of establishment, see Mustaki and Engammare (n 26) 6; On various entities being subjects of civil law, see J Frąckowiak, 'Adresaci norm prawa prywatnego - podmioty stosunków cywilnoprawnych' in J Gudowski, K Weitz (eds), Aurea praxis, aurea theoria. Ksiegga pamiatkowa ku czci Porfesora Tadeusza Erecińskiego, t. II (Warsaw 2011) 2263-2278.

43 See also Paweł Błaszczyk, 'Glosa do wyroku TS z dnia 12 lipca 2012 r., C-378/10' (2012) 11 Europejski Przegląd Sądowy 43; More precisely, the Member State of destination shall examine the documents certifying that the converting company has complied with all requirements laid down in the Member State of departure provided that those conditions are compatible with acquis communautaire, see Case C-378/10 VALE (n 25) para 61.

${ }^{44}$ See Case C-378/10 VALE (n 25), Opinion of Advocate General Jääskinen, para 11.

${ }^{45}$ Case C-378/10 VALE (n 25) para 58.

${ }^{46}$ See also Guzewicz (n 32) 641. 


\section{CONSEQUENCES OF RECOGNITION OF THE EU ENTITY}

In the VALE case, the Court of Justice ruled that a regulation that allows in a general manner (as in the case of the Hungarian provisions) for different treatment of domestic and foreign companies in relation to the transformation process is inconsistent with $\mathrm{EU}$ law ${ }^{47}$. A similar view was expressed earlier in the SEVIC case with regard to mergers of companies ${ }^{48}$. Moreover, for the purposes of cross-border conversion processes, the Court of Justice noted that the authorities of a Member State of destination are obliged to record in the commercial register the company of the Member State of origin as the 'predecessor in law' to the converted company, if such a record is possible in relation to domestic conversions ${ }^{49}$. However, the legislation of a Member State of destination may impose "strict legal and economic continuity between the predecessor company which applied to be converted and the converted successor company', provided that such a requirement is held in relation to domestic companies ${ }^{50}$.

The concept of an 'EU entity' fits perfectly into the context of maintaining the legal subjectivity of a converted company. This concept makes it possible to overcome the differences among the legal systems of particular Member States through acceptance of a legal fiction. This legal fiction is based on the assumption that there is an entity at the EU level that, having cited the Treaty provisions on freedom of establishment, may effect a cross-border transformation regardless of restrictions enacted in national legislation. Thus, once having fulfilled the requirements necessary for crossborder conversion, the regulations of the State of departure require the company's obligatory dissolution, it will be able to enjoy the status of 'EU entity' in the State of destination on condition that such a company fulfils the two conditions set out in Article 54 (1) TFEU. The first condition will be fulfilled as a matter of course because the company, in connection with the first incorporation, is already subject to the protection of freedom of establishment; deletion of the company from the register in the State of origin for the purposes of cross-border conversion, according to the proposed interpretation, can not thwart this effect. Therefore, the second condition, associated with having a seat in the territory of one of the Member States, will be decisive. When assessing the second condition, consideration might be made of the location of the central administration, which is the place where decision-makers are seated, or the principal place of business, i.e. the location where material resources and personnel (of the company) are concentrated. In order to ensure the protection of creditors and certainty of legal transactions, the register of the State of departure

\footnotetext{
${ }^{47}$ Case C-378/10 VALE (n 25) para 41. The VALE case is examined from the State of destination's point of view, therefore it refers to the situation of a company's immigration as opposed to the Cartesio case regarding a company's emigration. Both judicial decisions now constitute the basis for conducting the cross-border transformation of companies in the internal market. In both decisions the Court of Justice confirmed that the absence of rules laid down in secondary EU law cannot prevent the freedom of establishment from being exercised; see Cases C-378/10 VALE (n 25) para 38 and C-411/03 SEVIC Systems (n 35) para 26.

${ }^{48}$ C-411/03 SEVIC Systems (n 35) paras 22-23.

${ }^{49}$ Case C-378/10 VALE (n 25) para 56.

${ }^{50}$ Case C-378/10 VALE (n 25) para 55.
} 
should include a clear reference to which Member State the company is transferred; hence the process of conversion could be completed only in this Member State. This would serve as a basis to distinguish between definitive dissolution and liquidation of the company and the transfer of its business to another Member State. When these conditions are fulfilled, the cross-border conversion will not be blocked due to the fact the company ceased to exist ${ }^{51}$.

Recognition of the "EU entity' should strengthen the competitiveness of companies incorporated within the internal market in relation to companies operating outside from it (e.g. in the USA). Companies' supranational identity should affect cross-border reorganization processes through minimizing the occurrence of refusal of registration. At the same time, the authorities in the Member State of departure will be obliged to ensure that reliable and transparent information is easily available to creditors and minority shareholders. As far as this issue is concerned, a significant role should also be assigned in the future to the EU Companies' Register. A new legal instrument has recently been adopted: Directive 2012/17/EU of the European Parliament and of the Council of 13 June 2012 amending Council Directive 89/666/EEC and Directives 2005/56/EC and 2009/101/EC of the European Parliament and of the Council as regards the interconnection of central, commercial and companies registers ${ }^{52}$. This is a new challenge for EU institutions and Member States. As the European Parliament emphasized in its resolution of 7 September 2010 on the interconnection of business registers, the further integration of the European Economic Area can only be exploited if all Member States take part in the network $^{53}$. Cooperation between registers of all Member States will enable the processing of data concerning companies' legal and financial situation within the internal market. Each company will obtain a unique number in order to be easily identified within the European Economic Area ${ }^{54}$. Member States should ensure the reliability of documents and data. The coordination

\footnotetext{
${ }^{51}$ The success of cross-border transformation depends also on other factors, which is why adopting an act of European importance seems ultimately necessary. In the EU, there are already provisions relating to cross-border restructuring of companies which may be useful when it comes to establishing future regulations. At this point the following provisions should be noted: Directive 2005/56/EC of the European Parliament and of the Council of 26 October 2005 on cross-border mergers of limited liability companies [2005] OJ L 310/1 and Council Regulation 2001/2157/EC of 8.10.2001 on the Statute for a European company [2001] OJ L 294/1. The directive on the cross-border transfer of registered office was drafted but, work on it was discontinued (see inter alia Gert-Jan Vossestein, 'Transfer of the Registered Office: The European Commission's Decision Not to Submit a Proposal for a Directive' (2008) 4 Utrecht Law Review 58-61). On 14 January 2013 the European Commission started public consultation on the cross-border transfers of registered offices of companies. All citizens and organisations are welcome to contribute to this consultation (see http://ec.europa.eu/internal_market/consultations/2013/seat-transfer/index_en.htm). The consultation is the result of the adoption of the 'Action Plan' in December 2012 by the Commission: European company law and corporate governance (available at: http://ec.europa.eu/internal_market/company/modern/index_en.htm\#_actionplan2012), containing priorities regarding development of European company law for the coming years, among which intensification of legal actions related to cross-border operations was mentioned. In the near future, the EU's institutions should take legislative action towards regulation of cross-border conversion of companies.

52 [2012] OJ L156/1.

53 See Directive 2012/17/EU, para 7.

${ }^{54}$ See Directive 2012/17/EU, para 14
} 
of the different legal systems will strengthen economic cooperation in the European sphere.

\section{CONCLUSIONS}

A distinct separation of rights arising from European and national status may contribute to the strengthening of economic integration in the internal market. As in the case of EU citizenship, 'EU entity' status constitutes an independent category. Establishing the scope of rights arising from this status should take place gradually, as expressed in the decisions of the Court of Justice.

The development of European company law should be oriented towards the creation of favourable conditions for companies going through cross-border restructuring on the one hand, whereas on the other it should ensure protection of the interests of various entities, particularly creditors. The concept of 'EU entity' is suited to both of these purposes, therefore it is worth being developed by the Court of Justice in future judicial decisions.

National entities established on various grounds and having diverse internal structures should have an opportunity to appeal to their supranational identity when enjoying the freedom of establishment. Whether this status could become an autonomous one in the future, independent of particular domestic legal orders, remains an entirely different issue. 